\title{
Tigecycline-induced acute pancreatitis in a renal transplant patient: a case report and literature review
}

\author{
Jinwen Lin ${ }^{1,2,3}$, Rending Wang ${ }^{1,2,3}$ and Jianghua Chen ${ }^{1,2,3^{*}}$
}

\begin{abstract}
Background: The purpose of this case report is to increase the awareness of tigecycline-induced pancreatitis specifically in renal transplant patients predisposed to the condition.

Case presentation: A 48-year-old woman developed a donor-derived infection after kidney transplantation, resulting in a ruptured graft renal artery, followed by peritoneal drainage, blood and urine culture infections. Due to multiple drug resistance Acinetobacter baumannii cultured from the preservation fluid and blood, she was treated with tigecycline at the 8th post-transplant day combined with other antibiotics. After 15 days of tigecycline treatment, she was observed with recurrent fever and abdominal distension with a rise in pancreatic enzymes. CT scans showed acute pancreatitis with grade D on Balthazar score, no necrosis visible without contrast injection. These facts were sufficient to hint that pancreatitis was slowly becoming prominent. After withdrawal of tigecycline, CT scans showed that exudation around the pancreas were relieved, and blood amylase returned to the normal range in a week.

Conclusions: Clinicians should pay attention to clinical signs and symptoms and the level of serum pancreatic enzymes in order to monitor the development of pancreatitis. If necessary, abdominal CT scans should be performed regularly when given tigecycline.
\end{abstract}

Keywords: Tigecycline, Pancreatitis, Adverse events, Kidney transplantation

\section{Background}

Tigecycline was the first member in the glycylcycline class of antibacterial agents to be used clinically. It was approved by the US Food and Drug Administration (FDA) for the treatment of complicated skin and skin-structure infections (cSSSIs). Furthermore, it can be used for the treatment of complicated intra-abdominal infections (CIAI) caused by susceptible Gram-positive, Gram-negative and anaerobic organisms [1]. Tigecycline is a structural derivative of minocycline sharing similar pharmacokinetic properties and adverse effects with tetracyclines. The most common adverse effects associated with tigecycline are nausea, vomiting and diarrhea. Pancreatitis has been found to be associated with

\footnotetext{
* Correspondence: chenjianghua@zju.edu.cn

'Kidney Disease Center, the First Affiliated Hospital, College of Medicine,

Zhejiang University, Qingchun Road, Hangzhou 310003, China

${ }^{2}$ Key Laboratory of Kidney Disease Prevention and Control Technology,

Hangzhou, Zhejiang Province, China

Full list of author information is available at the end of the article
}

tetracycline. However, it was not listed as an adverse drug reaction in the product label when tigecycline was originally approved. A subsequent retrospective cohort analysis and a review of phase 3 and 4 comparative studies of tigecycline have also been performed with mixed conclusions $[2,3]$. As tigecycline has a broad spectrum, it has been used as part of the antimicrobial regimen for complicated infections in patients who had received an organ transplant. We report a case of tigecycline-induced acute pancreatitis after kidney transplantation and review the relevant literature.

\section{Case presentation}

A 48-year-old woman with end-stage renal disease (ESRD) due to chronic glomerulonephritis received a kidney transplant from a donor with DCD (donated cardiac death). The kidney was successfully transplanted to the recipient and normal serum creatinine levels were observed after 7 days. On the fourth day after transplantation, the patient was treated with teicoplanin, cefoperazone, sulbactam and 
etimicin due to the development of multiple drug resistance Acinetobacter baumannii in both organ preservation solution and drainage fluid. Tigecycline was administered intravenously at $100 \mathrm{mg}$ for the first dose and was given at $50 \mathrm{mg}$ every $12 \mathrm{~h}$ from the eighth day after the operation because of persistent abdominal infection. She felt pain at the transplant kidney area and then the blood pressure dropped to $88 / 61 \mathrm{mmHg}$ on the twentieth day after transplantation. Emergency ultrasound showed two huge hematoma around the graft. Graft pain relieved after emergency treatment including transplanted kidney exploration, renal hematoma removal, renal vascular reconstruction and ureteral reimplantation. The treatment with tigecycline was continued based on the results of the peritoneal drainage, blood and urine culture. The symptoms did not worsen until approximately 15 days after being initially administered. The patient presented with fever, nausea, vomiting and moderate abdominal pain. Physical examination found moderate tenderness in the upper abdomen. Laboratory analyses were remarkable for leukocytosis and the level of lipase raised to $156 \mathrm{U} / \mathrm{L}$. Other results such as serum amylase level was $424 \mathrm{U} / \mathrm{L}$ and drainage amylase was $554 \mathrm{U} / \mathrm{L}$, despite the aminotransferase and alkaline phosphatase were within the normal range. CT scans (Fig. 1a) suggested acute pancreatitis (AP) with grade D on Balthazar score, no necrosis visible without contrast injection. There was no sign of dilated biliary ducts according to the abdominal ultrasound examination. Since those findings were considered to be related to drug-induced pancreatitis, it was recommended that tigecycline should be discontinued on the 16th day following exposure. Shortly after tigecycline discontinuation, the patient's symptoms gradually improved. Blood amylase and lipase returned to baseline levels in a week. CT scans (Fig. 1b) showed a basically normal after tigecycline discontinuation for 14 days. She was discharged from the hospital with a low-fat diet for 3 weeks. One month later, abdominal CT scans on follow-up did not find any abnormalities and showed as normal (Fig. 1c). Throughout the course of treatment, the immunosuppressive regimen was a triple therapy based on recommended doses including tacrolimus, mycophenolate mofetil and prednisone. Serum tacrolimus concentration was maintained at $6-8 \mathrm{ng} / \mathrm{ml}$. The patient received these medications over the next 6 months, with no discomfort and relapse after stopping tigecycline. Timeline of disease was showed in Additional file 1: Figure S1.

\section{Discussion}

Infection from DCD donors is a major challenge in China. A recent study from China showed that $19.4 \%$ of donor blood cultures showed blood infection, consistent with the literature that about $5 \%-11.3 \%$ of donors did not find bacteremia on donation. Data from this singlecenter showed that the incidence of donor-derived bacterial infection was $4.5 \%[4,5]$. Because this patient's donor-associated pathogen was multidrug-resistant Acinetobacter baumannii, we added tigecycline to the antibiotic regimen based on Chinese expert consensus [6].

Tigecycline is the first member of a new class of antibiotics called glycylcyclines which was licensed by the US FDA in June 2005 for intravenous (IV) use in adults [7]. It inhibits bacterial protein synthesis by binding to the $30 \mathrm{~S}$ ribosomal subunit with a five-fold higher affinity than tetracycline [8]. Tigecycline is a derivative of minocycline, with a 9-t-butylglycylamido group added to the 1st carbon on the $\mathrm{D}$ ring of minocycline and it possesses a broad spectrum range. In 2008, tigecycline received FDA's approval for the treatment of adult patients with community-acquired bacterial pneumonia [9]. In vitro studies demonstrated that tigecycline exhibits a high level of antimicrobial activity against many common types of respiratory bacteria, including multiple resistant Gram-positive, Gram-negative, anaerobic, as well as multi-drug-resistant (MDR) pathogens, such as methicillin-resistant Staphylococcus aureus (MRSA) , vancomycin-resistant Enterococcus [10], penicillin-resistant Streptococcus pneumoniae (PRSP), methicillin-resistant
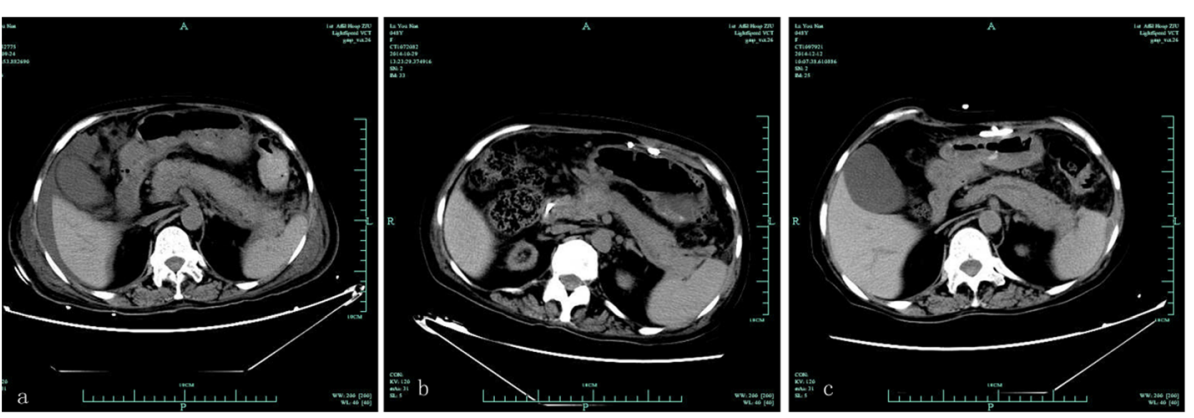

Fig. 1 image of CT scan during the the whole course of AP. a Twentie-five days post transplantation, the CT scan of abdomen showed pancreatic swelling, peripheral exudate effusion, considered acute pancreatitis (grade D on Balthazar score, no necrosis visible without contrast injection) after tigecycline treatment for 20 days. b scan showed a basically normal after tigecycline discontinuation for 14 days. c CT reported a normal finding after tigecycline discontinuation for 58 days 
Staphylococcus epidermidis (MRSE) and $\beta$-lactamaseproducing Haemophilus influenzae [11].

The most common adverse effects associated with tigecycline are nausea, vomiting and diarrhea. Pancreatitis has been reported that it could be induced by tetracycline, but it was not listed as an adverse drug reaction in the product label when tigecycline was originally approved. Concerns about tigecycline-induced AP have been raised by the clinicians in nearly 10 years [12-14]. Therefore, the former manufacturer of tigecycline, Wyeth, updated the product label including AP as one of the post-marketing adverse events in July 2006 [1]. Interestingly, although tigecycline was registered as a treatment for CIAI, it shoule be used causally when infectious complications were associated with acute pancreatitis because of the possible tigecycline-induced pancreatitis. This exclusion criteria might have emerged due to the similarities between tigecycline and other tetracyclines.

Biliary tract disease (40\%) and alcohol exposure (35\%) are common causes of AP. Other etiologies include idiopathic

Table 1 Review of cases report of tigecycline-induced acute pancreatitis — demographic data and drug characteristics

\begin{tabular}{|c|c|c|c|c|c|c|c|c|c|c|c|}
\hline Author & Country & $\begin{array}{l}\text { Number } \\
\text { of cases }\end{array}$ & $\begin{array}{l}\text { Year } \\
\text { of } \\
\text { report }\end{array}$ & $\begin{array}{l}\text { Age of } \\
\text { patient }\end{array}$ & Gender & $\begin{array}{l}\text { Indication of } \\
\text { tigecycline }\end{array}$ & Culture of specimens & $\begin{array}{l}\text { Duration } \\
\text { of } \\
\text { tigecycline } \\
\text { (days) }\end{array}$ & $\begin{array}{l}\text { Daily } \\
\text { dose } \\
\text { (mg) }\end{array}$ & $\begin{array}{l}\text { Combination } \\
\text { drug }\end{array}$ & $\begin{array}{l}\text { Hitory } \\
\text { of liver } \\
\text { disease }\end{array}$ \\
\hline Glison M & France & 1 & 2008 & 35 & Male & $\begin{array}{l}\text { Chronic } \\
\text { osteitis } \\
\text { complicated } \\
\text { by } \\
\text { pseudarthritis }\end{array}$ & $\begin{array}{l}\text { Enterobacter cloacae } \\
\text { with broad-spectrum } \\
\text { betalactamase }\end{array}$ & 15 & 100 & $\begin{array}{l}\text { Imipenem, } \\
\text { amikacin }\end{array}$ & None \\
\hline Lipshitz J & Usa & 1 & 2009 & 64 & Female & $\begin{array}{l}\text { Prosthetic } \\
\text { joint infection }\end{array}$ & NA & 14 & 100 & Levothyroxine, & None \\
\hline Marshall RS & USA & 1 & 2009 & 55 & Female & $\begin{array}{l}\text { Soft Tissue } \\
\text { Infection }\end{array}$ & $\begin{array}{l}\text { Enterococcus faecalis, } \\
\text { Pseudomonas } \\
\text { aeruginosa, and } \\
\text { Staphylococcus hominis }\end{array}$ & 14 & NA & $\begin{array}{l}\text { Pantoprazole, } \\
\text { and } \\
\text { hydromorphone. }\end{array}$ & None \\
\hline Hung WY & USA & 1 & 2009 & 69 & Female & $\begin{array}{l}\text { Soft tissue } \\
\text { infection/ } \\
\text { vascular graft } \\
\text { infection }\end{array}$ & $\begin{array}{l}\text { Coagulase-negative } \\
\text { Staphylococcus, } \\
\text { Staphylococcus } \\
\text { epidermidis and } \\
\text { diphtheroids, } \\
\text { Clostridium difficile }\end{array}$ & 8 & 100 & $\begin{array}{l}\text { Meropenem, } \\
\text { vancomycin, } \\
\text { clindamycin }\end{array}$ & None \\
\hline $\begin{array}{l}\text { Prot- } \\
\text { Labarthe S }\end{array}$ & France & 1 & 2010 & 9 & Male & $\begin{array}{l}\text { Bacteriemia / } \\
\text { arthritis }\end{array}$ & $\begin{array}{l}\text { Enterobacter cloacae } \\
\text { producing extended } \\
\text { spectrum betalactamase }\end{array}$ & 56 & 100 & $\begin{array}{l}\text { Colistin, } \\
\text { amikacin and } \\
\text { rifampin }\end{array}$ & None \\
\hline Otero RS & Mexico & 1 & 2010 & 27 & Female & $\begin{array}{l}\text { Acute } \\
\text { pneumonia }\end{array}$ & NA & 7 & 100 & $\begin{array}{l}\text { Amikacin, } \\
\text { oseltamivir }\end{array}$ & None \\
\hline Mascarello M & Italy & 1 & 2012 & NA & NA & $\begin{array}{l}\text { Chronic } \\
\text { osteomyelitis }\end{array}$ & $\begin{array}{l}\text { methicillin-resistant } \\
\text { Staphylococcus aureus, } \\
\text { multidrug-resistant } \\
\text { Pseudomonas aerugi- } \\
\text { nosa and Acinetobacter } \\
\text { baumannii }\end{array}$ & 12 & 100 & $\begin{array}{l}\text { Amikacin, } \\
\text { propofol }\end{array}$ & None \\
\hline Hemphill MT & USA & $1 s t$ & 2015 & 22 & Male & $\begin{array}{l}\text { Acute } \\
\text { bronchitis }\end{array}$ & M. chelonae & 14 & NA & $\begin{array}{l}\text { Tobramycin, } \\
\text { meropenem, } \\
\text { and vancomycin }\end{array}$ & None \\
\hline Hemphill MT & USA & 2nd & 2015 & 22 & Male & $\begin{array}{l}\text { Acute } \\
\text { bronchitis }\end{array}$ & M. chelonae & 3 & NA & $\begin{array}{l}\text { Amikacin, } \\
\text { clarithromycin }\end{array}$ & None \\
\hline Marot JC & Belgium & case 1 & 2012 & 64 & Male & $\begin{array}{l}\text { Soft tissue } \\
\text { infection }\end{array}$ & Staphylococcus aureus & 6 & 100 & None & None \\
\hline Marot JC & Belgium & case 2 & 2012 & 58 & Male & $\begin{array}{l}\text { Soft tissue } \\
\text { infection/ } \\
\text { osteomyelitis }\end{array}$ & $\begin{array}{l}\text { Staphyloccus scleiferi } \\
\text { methicillin-resistant and } \\
\text { Staphylococcus lugdu- } \\
\text { nensis methicillin- } \\
\text { sensitive }\end{array}$ & 8 & 100 & $\begin{array}{l}\text { Piperacillin- } \\
\text { Tazobactam, } \\
\text { Vancomycin }\end{array}$ & None \\
\hline Davido B & France & Case 1 & 2016 & 70 & Male & Pyelonephritis & ESBL Escherichia coli & 6 & 100 & None & None \\
\hline Davido B & France & Case 2 & 2016 & 50 & Female & $\begin{array}{l}\text { Femoral } \\
\text { osteomyelitis }\end{array}$ & EBSL E. coli, & 20 & 100 & $\begin{array}{l}\text { Imipenem } \\
\text { amikacin. }\end{array}$ & None \\
\hline
\end{tabular}


pancreatitis, post-endoscopic retrograde cholangiopancreatography, trauma, medications, infection, hypercalcemia, hypertriglyceridemia, tumor and autoimmune diseases. Several drugs are associated with AP. The overall incidence of drug-induced AP is $0.1 \% \sim 2 \%$ [15]. Medications associated with pancreatitis include tetracyclines, isoniazid, macrolides, metronidazole, propofol, angiotensin-converting enzyme inhibitors (ACEI), etc. [16].
The cause of drug-induced pancreatic injury is unknown. By using the classification of Zimmerman originally described for drug hepatotoxicity, drugs associated with tissuespecific injury can be divided into those with intrinsic toxicity in the organ involved and those that cause injury as a result of host idiosyncrasy [17]. As opposed to intrinsic toxicity, idiosyncratic reaction appears to be the mechanism of drug injury in the vast majority of cases. It is known that

Table 2 Review of cases report of tigecycline-induced acute pancreatitis - Clinical findings of cases

\begin{tabular}{|c|c|c|c|c|c|c|c|c|}
\hline Author & $\begin{array}{l}\text { Onset of } \\
\text { symptoms }\end{array}$ & $\begin{array}{l}\text { Clinical } \\
\text { manifestation }\end{array}$ & $\begin{array}{l}\text { Amylase/Lipase } \\
\text { levels }(\mathrm{U} / \mathrm{L})\end{array}$ & $\begin{array}{l}\text { CRP } \\
(\mathrm{mg} / \mathrm{l})\end{array}$ & CT scan & $\begin{array}{l}\text { AP } \\
\text { severity }\end{array}$ & $\begin{array}{l}\text { Time to } \\
\text { symptoms } \\
\text { relieved } \\
\text { (days) }\end{array}$ & $\begin{array}{l}\text { Time to } \\
\text { recovery } \\
\text { of } \\
\text { enzymes } \\
\text { (days) }\end{array}$ \\
\hline Glison M & $\begin{array}{l}13 \text { days, } \\
\text { abdominal } \\
\text { pain }\end{array}$ & $\begin{array}{l}\text { Acute abdominal } \\
\text { 'stab-like' pain }\end{array}$ & $(-) / 1000$ & 35 & $\begin{array}{l}\text { Pancreatic oedema without any necrotic } \\
\text { flows (Balthazar Stage 1). }\end{array}$ & Mild & 2 & 43 \\
\hline Lipshitz J & $\begin{array}{l}14 \text { days, } \\
\text { epigastric } \\
\text { pain }\end{array}$ & $\begin{array}{l}\text { Nausea, vomiting, } \\
\text { abdominal pain }\end{array}$ & $806 / 1406$ & NA & $\begin{array}{l}\text { Mild inflammatory stranding about the } \\
\text { duodenum and minimal fluid in the left } \\
\text { retroperitoneum. }\end{array}$ & Mild & 3 & 5 \\
\hline Marshall RS & $\begin{array}{l}3 \text { days, } \\
\text { uncontrolled } \\
\text { emesis }\end{array}$ & $\begin{array}{l}\text { Nausea, vomiting, } \\
\text { fever and loss of } \\
\text { appetite }\end{array}$ & $180 / 156$ & NA & Acute pancreatitis & Mild & 2 & 7 \\
\hline Hung WY & $\begin{array}{l}3 \text { days, } \\
\text { nausea and } \\
\text { vomiting }\end{array}$ & $\begin{array}{l}\text { Persistent and } \\
\text { worsening } \\
\text { nausea and } \\
\text { vomiting, } \\
\text { abdominal pain }\end{array}$ & $926 / 749$ & NA & NA & NA & 3 & 5 \\
\hline $\begin{array}{l}\text { Prot- } \\
\text { Labarthe S }\end{array}$ & $\begin{array}{l}14 \text { days, } \\
\text { abdominal } \\
\text { pain }\end{array}$ & $\begin{array}{l}\text { Abdominal pain, } \\
\text { recurrent } \\
\text { vomiting }\end{array}$ & $(-) / 603$ & NA & $\begin{array}{l}\text { Inflammation involving pancreas and } \\
\text { peripancreatic fat without necrosis } \\
\text { (Ranson Score } 2 \text { and Balthazar stage 2). }\end{array}$ & Mild & 3 & 5 \\
\hline Otero RS & 7 days & $\begin{array}{l}\text { Nausea, vomiting, } \\
\text { epigastric pain, } \\
\text { distention }\end{array}$ & $255 / 424$ & NA & $\begin{array}{l}\text { Pancreatic enlargement, low density } \\
\text { shadow of pancreas tail (grade D on } \\
\text { Balthazar score) }\end{array}$ & Mild & 3 & 12 \\
\hline Mascarello M & 12 days & $\begin{array}{l}\text { Nausea, vomiting } \\
\text { and acute severe } \\
\text { upper abdominal } \\
\text { pain }\end{array}$ & $312 / 382$ & 131 & $\begin{array}{l}\text { Inflammation of the pancreas and } \\
\text { peripancreatic fat, necrosis of } 40 \% \text { of the } \\
\text { pancreatic gland, peripancreatic } \\
\text { stranding, and fluid collection (Balthazar } \\
\text { CT severity index } 7 \text { ). }\end{array}$ & severe & $\leq 10$ & $\leq 10$ \\
\hline Hemphill MT & 10 days & Abdominal pain & NA/732 & NA & Acute pancreatitis & Mild & 6 & 6 \\
\hline Hemphill MT & 3 days & $\begin{array}{l}\text { Mild nausea, } \\
\text { epigastric } \\
\text { tenderness }\end{array}$ & $381 / 268$ & NA & Acute pancreatitis & Mild & 5 & 5 \\
\hline Marot JC & $\begin{array}{l}6 \text { days, } \\
\text { epigastric } \\
\text { pain }\end{array}$ & $\begin{array}{l}\text { Nausea, } \\
\text { epigastric pain }\end{array}$ & $750 / 936$ & NA & $\begin{array}{l}\text { An oedematous pancreatitis (grade D on } \\
\text { Balthazar score) }\end{array}$ & Mild & 4 & 18 \\
\hline Marot JC & $\begin{array}{l}7 \text { days, } \\
\text { abdominal } \\
\text { pain on day } \\
8\end{array}$ & $\begin{array}{l}\text { Nausea, vomiting } \\
\text { and loss of } \\
\text { appetite }\end{array}$ & $552 / 1660$ & NA & $\begin{array}{l}\text { Acute pancreatitis, no necrosis visible } \\
\text { without contrast injection (grade D on } \\
\text { Balthazar score) }\end{array}$ & Mild & 5 & 4 \\
\hline Davido B & 6 days, & $\begin{array}{l}\text { Anorexia, } \\
\text { vomiting and } \\
\text { abdominal } \\
\text { discomfort }\end{array}$ & NA/ 2460 & NA & $\begin{array}{l}\text { Typical oedematous infiltrate (Balthazar } \\
\text { A). }\end{array}$ & Mild & 2 & 2 \\
\hline Davido B & 20 days & $\begin{array}{l}\text { Nausea, } \\
\text { abdominal } \\
\text { discomfort }\end{array}$ & NA/ 1340 & NA & NA & NA & 1 & 1 \\
\hline
\end{tabular}


erythromycin stimulates motilin release which may induce AP by causing spasms of the sphincter of Oddi, leading to an abrupt of hypertension in the pancreatic duct and pancreatitis [18]. Unlike the erythromycin cause the host idiosyncrasy, the mechanism of tetracycline-induced pancreatitis is still unknown. There have been at least three mechanisms hypothesized, including formation of a toxic metabolite, hypertriglyceridemia and a high biliary concentration $[12,19,20]$. Tigecycline is structurally related to minocycline and shares similar pharmacokinetic properties and side effects with tetracyclines [21]. The diagnosis of druginduced AP is difficult to establish, mainly due to the absence of cause-specific diagnostic tests. Therefore, it is usually based on the following criteria: (1) AP occurs during the administration of a drug. [22] All other common causes are excluded. (3) Symptoms of AP disappear after drug withdrawal. (4) Symptoms recur after a rechallenge of the suspected drug [23]. A total of 10 literatures were collected from the database, which met the above inclusion criteria, involving a total of 12 cases with 13 occasions. [12-14, 16, 21, 24-27]. (Tables 1 and 2) At the same time, the included literature should include the general condition, past history, clinical manifestations of acute pancreatitis, CT scan, daily dose, combination drug therapy, symptom relief time, recovery time, medication time, enzyme recovery time and other information.

Tetracycline-induced AP is closely related to the underlying liver disease in patients $[20,28]$. For patients without a history of liver disease, the onset of AP caused by tetracycline for anti-infection therapy ranged from 4 months to 2 years with an average total daily dose of $1083 \sim 1353 \mathrm{mg} / \mathrm{d}$. However, for those patients with severe hepatic dysfunction, the course of tetracycline lasted for $8 \sim 17$ days with an average total daily dose of $1500 \sim 4000 \mathrm{mg} / \mathrm{d}$ [29]. Recovery time of amylase and lipase to the normal range was within $13 \sim 21$ days. In our review, the administration of tigecycline for the 12 patients was all in accordance with the specification, which indicated that there was no significant correlation between AP and medication. If patients had no history of liver disease, tigecycline-induced acute pancreatitis was more rapid compared to tetracycline. Meanwhile, after withdrawal of tigecycline, the symptoms were relieved more quickly and the time for serum lipase and amylase decline was also shorter.

Twelve patients were given anti-infective drug combination therapy. Moreover, most of the drugs for discontinuation of tigecycline were still used continually. In some cases, propofol increases serum triglyceride levels and may cause AP. However, the patient did not have any hyperlipidemia, and neither of the previous propofol uses caused pancreatitis [30]. There was no evidence that aggravating pancreatitis was associated with propofol combination therapy. Our patient was taking several additional drugs possibly. However, during treatment or ceasing of tigecycline, she has been taking these medications at recommended dose which were associated with pancreatitis and classified as group III (prednisone) and group IV (tacrolimus), respectively (low risk) [18]. Therefore, we do not think that combination therapy in this situation may lead to acute pancreatitis.

The increasing degree of amylase and lipase is not directly related to the severity of AP. Lipshitz J et al. reported the serum lipase and the amylase were as high as $806 \mathrm{UI} /$ $\mathrm{L}$ and $1406 \mathrm{UI} / \mathrm{L}$ in patients with abdominal pain associated with nausea and vomiting, while CT scans showed duodenal mild inflammation and left posterior abdominal effusion [13]. However, Mascarello $\mathrm{M}$ et al. reported that serum lipase and amylase were $382 \mathrm{UI} / \mathrm{L}$ and $312 \mathrm{UI} / \mathrm{L}$ respectively in patients with similar symptoms [31]. CT scans showed severe pancreatitis inflammation with $40 \%$ pancreatic and peripancreatic necrosis and fluid retention, and the Balthazar classification was E level with CTSI score 7 points. It should be noted that the final time to normalize serum lipase and amylase was not directly related to serum lipase and amylase levels.

Finally, tigecycline induced AP is still considered to be a rare phenomenon. However, serum amylase and lipase levels should be closely monitored if any symptomatic abdominal pain suggests AP during treatment. In addition, the mechanism of tigecycline-induced AP and the possibility of cross-reactivity with tetracycline in patients with AP induced by tigecycline should be given more attention. Whether tigecycline increases the risk of pancreatitis in immunosuppressed recipients requires more research data.

\section{Conclusions}

Clinicians should pay attention to clinical signs and symptoms and the level of pancreatic enzymes in the blood in order to monitor the development of pancreatitis. Abdominal CT images should be taken on a regular basis when necessary for the administration of tigecycline.

\section{Additional file}

\section{Additional file 1: Figure S1. Timeline. (DOC $70 \mathrm{~kb}$ )}

\section{Abbreviations}

ACEl: Angiotensin-converting enzyme inhibitors; AP: Acute pancreatitis; CIAI: Complicated intra-abdominal infection; cSSSIs: Complicated skin and skin-structure infections; CT: Computed Tomography; CTSI: CT severity index; DCD: Donation Cardiac Death; ERCP: Endoscopic retrograde

cholangiopancreatography; ESRD: End-stage renal disease; FDA: Food and Drug Administration; IV: Intravenous; MDR: Multidrug-resistant;

MRSA: Methicillin-resistant Staphylococcus aureus; MRSE: Methicillin-resistant Staphylococcus epidermidis; PRSP: Penicillin-resistant Streptococcus

pneumoniae; VRE: Vancomycin-resistant Enterococcus 


\section{Availability of data and materials}

Ct scan images of case were obtined from the First Affiliated Hospital, College of Medicine, Zhejiang University.

\section{Authors' contributions}

JWL and RDW searched the database for the literature and drafted the manuscript. JHC submitted case report and provided guidance for drafting the manuscript. All authors read and approved the final manuscript.

\section{Authors' information}

Jinwen Lin is studying for her doctor's degree and is also currently a physician in Kidney Disease Center, the First Affiliated Hospital, College of Medicine, Zhejiang University, Hangzhou, China. Jianghua Chen is the director of Kidney Disease Center in the same hospital.

\section{Ethics approval and consent to participate}

Written informed consent for publication of their clinical details and clinical images was obtained from the patient. This case report was a retrospective investigation and was not necessary for ethics approval. Ethics approval is not applicable

\section{Consent for publication}

All named authors have read the manuscript and have agreed to submit the paper to BMC Infectious Disease in its present form. The research has not been and will not be submitted simultaneously to another journal, in whole or in part. The paper reports previously unpublished work. All those named as authors have made a sufficient contribution to the work. Written informed consent for publication of their clinical details and clinical images was obtained from the patient.

\section{Competing interests}

The authors declare that they have no competing interests.

\section{Publisher's Note}

Springer Nature remains neutral with regard to jurisdictional claims in published maps and institutional affiliations.

\section{Author details}

'Kidney Disease Center, the First Affiliated Hospital, College of Medicine, Zhejiang University, Qingchun Road, Hangzhou 310003, China. ${ }^{2}$ Key Laboratory of Kidney Disease Prevention and Control Technology, Hangzhou, Zhejiang Province, China. ${ }^{3}$ The Third Grade Laboratory under the National State, Administration of Traditional Chinese Medicine, Hangzhou 310003, China.

Received: 27 May 2017 Accepted: 19 April 2018

Published online: 02 May 2018

\section{References}

1. Wyeth Pharmaceutics. Tygacil ${ }^{\oplus}$ (package insert). Philadelphia: Wyeth Pharmaceutics. Tigecycline is a structural derivative of minocycline and shares similar pharmacokinetic properties and most of the adverse effects with tetracyclines; 2009

2. Okon E, Engell C, van Manen R, Brown J. Tigecycline-related pancreatitis: a review of spontaneous adverse event reports. Pharmacotherapy. 2013;33:63-8.

3. McGovern PC, Wible M, Korth-Bradley JM, Quintana A. Pancreatitis in tigecycline phase 3 and 4 clinical studies. J Antimicrob Chemother. 2014;69:773-8

4. Ye QF, Zhou W, Wan QQ. Donor-derived infections among Chinese donation after cardiac death liver recipients. World J Gastroenterol. 2017;23: 5809-16.

5. Gonzalez-Segura C, Pascual M, Garcia Huete L, Canizares R, Torras J, Corral L, Santos P, Ramos R, Pujol M. Donors with positive blood culture: could they transmit infections to the recipients? Transplant Proc. 2005:37:3664-6.

6. Chen $B Y, H e L X, H u B J$. Consensus of the Chinese specialists for diagnosis, treatment \& control of acinetobacter baumannii infection. Zhonghua Yi Xue Za Zhi. 2012;92:76-85.

7. Mullangi PK, Pankey GA. Tigecycline in critical care. Crit Care Clin. 2008;24: 365-75. $x$
8. Zhanel GGHK, Nichol K, Noreddin A, Vercaigne L, Embil J, Gin A, Karlowsky JA, Hoban DJ. The glycylcyclines: a comparative review with the tetracyclines. Drugs. 2004;64:63-88.

9. Tanaseanu C, Bergallo C, Teglia O, Jasovich A, Oliva ME, Dukart G, Dartois N, Cooper CA, Gandjini H, Mallick R. Integrated results of 2 phase 3 studies comparing tigecycline and levofloxacin in community-acquired pneumonia. Diagn Microbiol Infect Dis. 2008;61:329-38.

10. Duprey A, Chavent B, Maillard N, Mariat C, Alamartine E, Albertini JN, Favre JP, Barral X. Common hepatic artery as inflow in kidney transplantation. Am J Transplant. 2015;15:2991-4.

11. Bhattacharya M, Parakh A, Narang M. Tigecycline. J Postgrad Med. 2009;55: 65-8.

12. Gilson $M$, Moachon $L$, Jeanne $L$, Dumaine $V$, Eyrolle $L$, Morand $P$, Ben m'Rad $M$, Salmon D. Acute pancreatitis related to tigecycline: case report and review of the literature. Scand J Infect Dis. 2008:40:681-3.

13. Lipshitz J, Kruh J, Cheung P, Cassagnol M. Tigecycline-induced pancreatitis. J Clin Gastroenterol. 2009:43:93.

14. Marshall S. Tigecycline-induced pancreatitis. Hosp Pharm. 2009;44:239-41.

15. Balani AR, Grendell JH. Drug-induced pancreatitis : incidence, management and prevention. Drug Saf. 2008;31:823-37.

16. Hung WY, Kogelman L, Volpe G, lafrati M, Davidson L. Tigecycline-induced acute pancreatitis: case report and literature review. Int J Antimicrob Agents. 2009;34:486-9

17. Zimmerman HJ. Hepatoxicity. The adverse effects of drugs and other chemicals on the liver. New York: Appleton-Century-Crofts; 1978. p. 91-5.

18. Badalov N, Baradarian R, Iswara K, Li J, Steinberg W, Tenner S. Drug-induced acute pancreatitis: an evidence-based review. Clin Gastroenterol Hepatol. 2007;5:648-61. quiz 4

19. Steinberg WM. Acute drug and toxin induced pancreatitis. Hosp Pract. 1985; 20:95-102.

20. Elmore MF, Rogge JD. Tetracycline-induced pancreatitis. Gastroenterology. 1981:81:1134-6.

21. Marot JC, Jonckheere S, Munyentwali H, Belkhir L, Vandercam B, Yombi JC Tigecycline-induced acute pancreatitis: about two cases and review of the literature. Acta Clin Belg. 2012;67:229-32.

22. de Mattos AM, Siedlecki A, Gaston RS, Perry GJ, Julian BA, Kew CE 2nd, Deierhoi MH, Young C, Curtis JJ, Iskandrian AE. Systolic dysfunction portends increased mortality among those waiting for renal transplant. J Am Soc Nephrol. 2008:19:1191-6.

23. McArthur KE. Review article: drug-induced pancreatitis. Aliment Pharmacol Ther. 1996;10:23-38.

24. Prot-Labarthe SYR, Benkerrou M, Basmaci R, Lorrot M. Pediatric acute pancreatitis related to tigecycline. Pediatr Infect Dis J. 2010;29:890-1.

25. Otero RS, López DE, Ponce AP, Ponce CC. Pancreatitis probablemente inducida por tigeciclina: reporte de un caso. Medicina Interna de México. 2010;26:273-5.

26. Hemphill MT, Jones KR. Tigecycline-induced acute pancreatitis in a cystic fibrosis patient: a case report and literature review. J Cyst Fibros. 2016:15:e9-11.

27. Davido B, Shourick J, Makhloufi S, Dinh A, Salomon J. True incidence of tigecycline-induced pancreatitis: how many cases are we missing? J Antimicrob Chemother. 2016;71:2994-5.

28. Nicolau DP, Mengedoht DE, Kline JJ. Tetracycline-induced pancreatitis. Am J Gastroenterol. 1991;86:1669-71.

29. Kunelis $C T$, Peters $J$, Edmondson HA. Fatty liver of pregnancy and its relationship to tetracycline therapy. Am J Med. 1965:38:359-77.

30. Jawaid Q, Presti ME, Neuschwander-Tetri BA, Burton FR. Acute pancreatitis after single-dose exposure to propofol: a case report and review of literature. Dig Dis Sci. 2002;47:614-8.

31. Mascarello MPG, Arnez ZM, Luzzati R. Acute necrotizing pancreatitis related to tigecycline. J Antimicrob Chemother. 2012;67:1296-7. 